ENCYCLOPÉDIE Encyclopédie berbère

BERBERE

5 | 1988

5 | Anacutas - Anti-Atlas

\title{
Aneiritae ou Aneritae
}

\section{J. Desanges}

\section{OpenEdition}

Journals

Édition électronique

URL : http://journals.openedition.org/encyclopedieberbere/2505

DOI : 10.4000/encyclopedieberbere.2505

ISSN : 2262-7197

\section{Éditeur}

Peeters Publishers

\section{Édition imprimée}

Date de publication : 1 avril 1988

Pagination : 657

ISBN : 2-85744-379-6

ISSN : 1015-7344

\section{Référence électronique}

J. Desanges, «Aneiritae ou Aneritae », Encyclopédie berbère [En ligne], 5 | 1988, document A219, mis en ligne le 01 décembre 2012, consulté le 16 octobre 2020. URL : http://journals.openedition.org/ encyclopedieberbere/2505; DOI : https://doi.org/10.4000/encyclopedieberbere.2505

Ce document a été généré automatiquement le 16 octobre 2020

(C) Tous droits réservés 


\section{Aneiritae ou Aneritae}

\section{J. Desanges}

1 Les Aneiritae ou Anêritae sont placés par Ptolémée (IV, 5, 12, éd. C. Müller, p. 692) en bordure côtière de la Marmarique, entre les Libuarkhae et les Bassakhitae. On hésitera à rapprocher leur nom de celui d'un district de la Marmarique, le district des Eṇzêrețae, cf. C. Wessely, Ptolémée, " Géographie », IV, 5, 24 et le " Papyrus Rainer » n²59, dans R.E.G., XXXII, 1919, p. 505-506 C. Wessely utilise la numérotation de l'édition Nobbe de Ptolémée). Ce district comporte un secteur rural nommé Mokkhuris, cf. Ptolémée (IV, 5, 13, p. 695) : Mokkhuris ou Mokkhêris ; M. Norsa et G. Vitelli, « Il Papiro Vaticano greco 11 ", $2^{\mathrm{e}}$ partie : Registri fondiari della Marmarica, Città del Vaticano, 1931, p. 55 (V, 5 et 18) : Mokhlhuris (époque de Commode) ; Itin. Ant., 69, 1 : Michera ou Mecyra siue Elene ; 71, 4 : Micera ; Table de Peutinger, IX, 1 : Meciris, à 22 milles (33 km) d'Antipego (Tobrouk), sur la voie Cyrène-Tobrouk. Si le rapprochement entre les Aneiritae ou Anêritae et les Eṇzêrețae, dont on lit mal le nom, était fondé, il faudrait donc localiser cette tribu à l'ouest de Tobrouk.

\section{INDEX}

Mots-clés : Antiquité, Tribus 